\title{
Flavonoids content in methanolic extract of Equisetum arvense L.(Horsetail) from Kurdistan region - Iraq
}

\author{
Ismail AM Al-Khasreji TO* Maulood BK** \\ Biology Department / College of Science for Women / Baghdad University \\ * Biology Department / College of Education for Pure Science / University of Tikrit \\ ** Biology Department / College of Science / University of Salahdeen \\ E-mail: abbasmurtadeh@gmail.com
}

\begin{abstract}
Background:The ferns are well known that they are a rich sources to bioactive compounds mainly flavonoid groups which are very important to protect these plants from environmental stresses. Objective: The object of this work is to determine chemical content (total flavonoids) in methanol extract of Equisetum arvense L. Family Equisetaceae.

Methods: mature sporophyte of the fern was collected from Chemi Rezan region in Sulaimaniyah district during May 2016. The methanol extract of the fern was prepared by using Soxhulet apparatus to be used for phytochemical analysis.

Resulrs: The outcome of the qualitative analysis for $E$. arvense extract had showed that the fern was containing active compounds which involve: alkaloids, saponins, tanins and four flavonoids which were identified as: kaempferol, aempferol-O-3- glycoside, leutolin, and querctin in E. arvense by using HPLC technique. In fact the main compound leutolin $(100.6 \mu \mathrm{g} / \mathrm{ml})$ was recorded quit high concentration. The results were showed that total flavonoids made up almost $(179.5 \mu / \mathrm{ml})$.

Conclusion: It was found that total flavonoid have positive correlation with the environment in the studied region.
\end{abstract}

Key words: Ferns, Equisetum, Iraqi Kurdistan, Flavonoids.

\section{Introduction}

Equisetum is the only living genus belongs living family Equisetaceae, order Equisetales, class Equisetopsida. E. arvense L. is a medicinal fern that was found in the America, Northern Africa and Asia (1). The fern commonly named (horsetail, scouring rush), which is traditionally uses for a wide range of illnesses treatment as a diuretic, ant edematous, anti-inflammatory and demineralizing (2). Scientific research was indicated that nearly of $10 \%$ of flavonoids was identified in the fern, primarily as the kaempferol, apigenin, luteolin, quercetin, rutin, myrctine, and glycosids (3). The fern present medicinal uses as an anti-inflammatory agent for skin disease in America and Asia as well as antiseptic in America and Turky (4). In addition the plant accumulates hihgi amount of Sillicats, it contains a number of flavonoids such as rutine and kaempferol 3-O- glycosides as well as Querctin (5). According to the recent studies on the ferns Northern Iraq, 16 species present belongs five families and 9 genera were documented $(6,7)$. These species in Kurdistan of Iraq represents a range of microhabitats from semiarctic zones to high humid mountains $(8,9,10,11,12)$. The genus Equisetum is the only remaining representative of the once abundant and divers class Equisetopsida (9). Recent phylogenetic studies suggest that perhaps should be classified within the true ferns $(13,14)$. The Equisetum genus consists of 15-25 species of horsetail and perennial ferns (9). Fern plants were found in diverse habitats: open grassland, along marshes, streams, digest, river banks, wetlands and swamps $(15,16)$. Secondary metabolits such as Flavonoids are the most important groups of 
defense bioactive compounds in plants and good sources of natural antioxidants in plants and human diets $(17,18)$. The aim of this work was to determine the total flavonoids in E. arvense which has a new addition to the fern chemistry to the pteridoflora flora Iraqi kurdistqan.

\section{Materials and Methods}

\section{Plant collection}

Equisetum arvense samples were collected from Chemi Rezan region during Summer of 2016. Plant photograph was sent and identified by Dr. Ihsan Shahbaz of Mizzory Botanical Garden in USA. A voucher samples no. (4, 19, 5, Eq. ar) has been deposited at the Herbarium of Howler Botanical Garden- Erbil Governorate. Geographical aspects (using GPS) and meteorological data (FROM Sulaymaniyah meterology stasion) of the study area were documented and presented in Table $(1,2)$.

Table (1): Geographical characters of the studied region

\begin{tabular}{|c|c|c|c|}
\hline Region & Elevation (m) & Longitude & Latitude \\
\hline Chemi Rezan & 755 & $\mathbf{3 5}^{\circ} 55.70 \mathrm{~N}$ & $\mathbf{4 4}^{\circ} \mathbf{4 3 . 5 9} \mathrm{E}$ \\
\hline
\end{tabular}

Table (2): Meteorological data (annual mean) of the studied region

\begin{tabular}{|c|c|c|c|}
\hline Region & Temperature $\left(\mathbf{c}^{\circ}\right)$ & Rainfall $(\mathbf{m m})$ & Humidity (\%) \\
\hline Chemi Rezan & 36 & $\mathbf{1 7 1 . 5}$ & $\mathbf{6 5}$ \\
\hline
\end{tabular}

\section{Preparation of Row materials}

The aerial parts of fern sample were washed with tap water followed by distilled water. The sample was dried at the laboratory temperature for a week, the shade dried sample was ground to powder using electrical grinder and then the powdered sample was stored in dry container.

\section{Crude extract preparation}

The powdered plant ten grams was extracted with 1: 10 of methanol (BDH) 99\% using a soxhlet apparatus (temperature $40 \mathrm{c}^{\mathrm{o}}$ for 24 houre). The methanol extraction was filtered through Whatman filter No.1, after filtration the supernatant was dried in vacuum desiccator and then the dried extract was stored in freeze.

\section{Phytochemical analysis}

Qualitative analysis of the fern extract was carried out in advanced Biotechnology laboratory of Baghdad University - College of science, following procedure described by (19).

\section{HPLC analysis}

The crud extract $(10 \mu \mathrm{g})$ was analyzed in $100 \mathrm{ml}$ mobile phase (methanol alcohol 99\% BDH), after filtering through a filter paper $(0.45 \mu)$, the extract was injected into HPLC instrument by an auto sampler according to the optimum condition. The main compound was separated on FLC column: C18-DB, $3 \mu \mathrm{m}$ particle size (50X $2.0 \mathrm{~mm}$ I.D) column, mobile phase: linear gradient of, solvent A $0.05 \%$ trifloroacetic acid (TFA acid) in deionized water: solvent $\mathrm{B}$ was $0.05 \%$ TFA in methanol, $\mathrm{pH}, 2.5$ gradient program from $0 \% \mathrm{~B}$ to $100 \%$

B for 10 minutes.

Flow rate $1.1 \mathrm{ml} / \mathrm{min}$.

Detection: UV at $280 \mathrm{~nm}$. 


\section{Calculation}

Sample conc. $\boldsymbol{\mu g} / \mathbf{m l}=$ sample aerea $/$ standard aerea $X$ standard conc. $X$ dilu. factor. The compounds seperation on liquid chromatography Shimadzu 10 AV- LC equipped with binary delivery pump model LC10A Shimadzu, Japan) the eluted peaks were monitored by UV- Vis 10 A- SPD spectrophotometer (20). HPLC analysis revealed four major peaks in the retention time were presented in Table (3).

Table (3): Standard flavonoids, retention time $\&$ area

\begin{tabular}{|c|c|c|c|}
\hline No. & Flavonoids & Retention time (min) & Area \\
\hline 1 & Qurcetine & 1.25 & 67880 \\
\hline 2 & Luteoline & 3.47 & 114892 \\
\hline 3 & Kaempferol & 4.37 & 109560 \\
\hline 4 & kaempferol-3-O-glycosid & 5.29 & 107439 \\
\hline
\end{tabular}

\section{Results and Discussion}

\section{Screening of chemicals:}

Qualitative analysis of fern crude extract was revaeled the positive detections of main bioactive compounds which were: alkaloids, saponins, tannins and flavonoids were summarized and presented in Table (4).

Table (4): Qualitative analysis of phytochemicals in fern extract

\begin{tabular}{|c|c|c|c|c|}
\hline Material & Alkaloids & Flavonoids & Tannins & Saponins \\
\hline Fern extract & ++ & ++ & ++ & ++ \\
\hline
\end{tabular}

\section{HPLC analysis:}

The quantitative analysis of methanolic extract was revealed the flavonoids concentrations in E. arvense methanolic extract Table (5).

Table (5): Concentrations of total flavonoids $(\mu \mathrm{g} / \mathrm{ml})$ in fern extract

\begin{tabular}{|c|c|c|c|c|c|}
\hline Material & Quercetin & $\begin{array}{c}\text { Kaempf } \\
\text { erol }\end{array}$ & $\begin{array}{c}\text { Kaempferol_3_ } \\
\text { o__ }_{-} \\
\text {glycoside }\end{array}$ & Luteolin & Total \\
\hline $\begin{array}{c}\text { Fern } \\
\text { extract }\end{array}$ & 9.9 & 26.6 & 42.4 & 100.6 & 179.5 \\
\hline
\end{tabular}


The results of qualitative study of methanol fern extract were showed the presence of four bioactive compounds which were: saponins, tannins, alkaloids and flavonoids, Table (4). Results of chemical analysis in the fern extract was agreed with $(21,22)$.

HPLC analysis for methanolic extract of the fern were using four standard flavonoid compounds which were revealed the presence of four flavonoids which were: kaempferol, kaempferol-3-o- glycoside, leutolin and qurectin in E. arvense, luteolin was recorded the highest concentration $(100.6 \mu \mathrm{g} / \mathrm{ml})$ and the concentration of total flavonoid $179.5 \mu \mathrm{g} / \mathrm{ml}$ in fern extract Table (5). So phenolic and other active compounds act as chemical interface between plants and environment. Flavonoids play very important role in protection against environmental stresses (mainly abiotic), but also these compounds reacts with microorganisms such as (nematods, fungi, etc.) and other associated plants $(23,24)$. Recent phytochemical investigations on the fern extract have led to characterization many bioactive compounds such as flavonoids mainly were recorded in the E. arvense L. $(3,12,21,20)$.

\section{References}

1. Radulovic N, Stojunavic G, Palic R. Composition and antimicrobial activity of E. arvense L. Essential oil. Phytotheropy Resaerch. (2006); 20: 85-88.

2. European Medical Agency - EMEA. Committee on Herbal Medicinal Products, List of References Supporting the Assessment Report on: Equisetum arvense, London: European Medicines Agency Evaluation of Medicines for Human Use. (2008): 1-41.

3. Sandhu NS, Kaur S, Chopra D, Equietum arvense: Pharmacology and phytochemistry - a review, Asia Pac. J. Pharmacol. (2010); 3: 146-150.

4. Ody P, Kindersley D. The complete medicinal herbal. New York: DK Publishing. (1993).

5. Veit M, Beckeret C, Hohne C, Bauer K, Geiger H. Interspecific and intraspecific variation of phenolics in the genus Equisetum subgenus Equisetum. Phytochemistry. (1995); 38: 881-891.

6. Townsend CC, Guest E. Flora of Iraq. Ministry of Agriculture, Baghdad. Iraq. Vol.2 . (1966); pp-184.

7. Chakravarty HL. Plant wealth of Iraq. Ministry of Agriculture and Agrarian Reform. vol. 1: (1976); pp505 .

8. Al-Rawi A. Wiled plants of Iraq with their distribution. Ministry of Agriculture and Irrigation, Baghdad, Iraq. (1988); pp-232.

9. Maulood BK, Al-Khasreji TO, Ismail AM. A study on Pteridoflora of Kurdistan of Iraq: A morphological study and distribution of Equisetum L. (Horsetail) in Iraqi Kurdistan. International J. of Emerging Technologies in Computational and Applied Sciences. (2016); 18(1): 78-84.

10. Ismail, A.M. Biological and molecular study on the ferns in three districts North of Iraq. Ph. D Thesis Tikrit University. (2018); pp: 211.

11. Ismail AM, AL-Khasreji TO, Maulood BK. Phytochemical and antioxidant activity of Asplenium species (spleen worts) extracts from Northern districts of Iraq. Engineering and Technology Journal . (2019); $37(2 \mathrm{C}): 248-251$.

12. Ismail AM, Ouaid T, AL-Amery M, Maulood BK. A preliminary study of phytochemicals of Equisetum arvense L. \& E. ramosissimum Desf. (Equisetaceae) extracts from Northern of Iraq. Fern Gazzet . (2020); 21(3): 125-130. 
13. Smith AR, Kathleen M. Pryer ,Erie Schuettpetz ,Pera Korala ,Harald \& Paul G .Wolf . A classification for extant ferns. Journal of Taxon . (2006); 55(3): 705-731.

14. Pryer KM, Schnider H, Smith AR, Cranfil R, Wolf PG, Hunt JS , Sipes SD. Horsetails and ferns are a monophyletic group and the closest living relatives to plants. Nature. (2001); 409: 618-622.

15. Amit S, Saraswati B, Kamalesh U, Kumud U. Formation and evaluation of a novel herbal gel of Equisetum arvense extract. Journal of pharmacognosy and phytochemistry. (2013); 1(5): 80-86.

16. Brownsey PJ , Perrie LR. Flora of Newzland ferns and lycopods- Equisetaceae. (2015):1-13.

17. DO Montae FH, DO Santos JG, Russi JR, Lanziotti VM, Leal GM, Cunhab GM. Anti -nociceptive and anti-inflammatory properties of the hydroalcholic extract of stems from Equisetum arvense L. in mice. Pharmacological Research. (2004); 49: 239-243.

18. Jain A, Jain D, Shrivastava S. A short review on pharmacological activity of Equisetum ramosissimum. Asian J. of pharmacological education and research. (2016); 5(4): 1-8.

19. Harborne JB. Methods of extraction and isolation. In: phytochemical methods, Chapman \& Hall, London. (1998): 60-66.

20. Suarez B, Palascios N, Fraga N, Rodrigue R. Liquid Chromatographic method for quantifying polyphenols in ciders by direct injection . Journal of Chromatography A, 1066. (2005): 105-110.

21. Asgarpanah J, Elnaz R. Phytochemistry and pharmacological properties of Equisetum arvense L. Journal of medicinal plants Rese.(2012); 6(21): 3689- 3693.

22. Hoque AS, Bithica G, Rimlee N, Roy BN, Pallab K. Pharmacognostical evaluation and phytochemical screening of the plant Equisetum arvense L. World J of Pharmacy and Pharmaceutical Sciences.

(2016); 5(5): 1537-1543.

23. Mierziek J, Kostyn K, Kulma A. Flavonoids as important molecules of plant interaction with environment. Molecules . (2014); 19: 16240- 16265.

24. Gobbo-Neto L, Lopez NP. Plants medicinal factors de influencia no conteudo de metabolits secondatros. Quim Nova . (2007); 30: 374-381. 